\title{
Failing adaptation in island contexts: The growing need for transformational change
}

\author{
Patrick D. Nunn and Karen E. McNamara
}

\begin{abstract}
Many islands are being visibly impacted by climate change to which they are disproportionately exposed. This situation requires a shift away from reactive shortterm responses to longer-term transformational adaptation. For this to be effective, the singularity of island environments and societies should be acknowledged and optimal ways of management and engagement identified. There is considerable potential to learn from past intervention failures in island contexts.

The importance of aligning adaptation needs with interventions underpins such transformational change, which on islands principally involves the relocation of vulnerable (coastal) communities and infrastructure to less-vulnerable (inland) places, as well as other transformations such as changing livelihoods and qualityof-life improvements. Successful transformational adaptation also requires that all actors involved change their current attitudes and re-evaluate how they can contribute to adaptation that is effective and sustainable in island contexts.
\end{abstract}

Cite this article: Nunn, P.D. \& McNamara, K.E. (2019): Failing adaptation in island contexts: The growing need for transformational change. In: Klöck, C. \& Fink, M. (eds.): Dealing with climate change on small islands: Towards effective and sustainable adaptation? (pp. 19-44). Göttingen: Göttingen University Press. https://doi.org/10.17875/gup2019-1210 


\section{Background: Climate-change challenges for island peoples}

If one understands the science, then one knows the future is quite bleak for us all. As Head (2016) argues, we must mourn the future lost, otherwise we will continue to live in denial. For some small islands, the reality is that in the next ten to twenty years, coastlines will become uninhabitable. With this in mind, this chapter discusses transformational long-term approaches to adaptation in preference to shortterm solutions that have driven most responses to adaptation to date. Throughout the Pacific Islands, people have significant internal resources and have a long history of adapting to environmental change (Nunn, 2007; Barnett, 2017; BryantTokalau, 2018). Yet sinking piles of money into short-sighted 'solutions' is not the answer. This chapter offers pragmatic insights into this confronting reality.

As is implicit in the IPCC's designation of 'small islands' as separate chapters in their last two assessment reports (Mimura et al., 2007; Nurse et al., 2014), such islands are recognised as uniquely and disproportionately exposed to climate change, recent and future. This is explainable largely by their high coastline to land area ratios, especially those at the lower end of the size spectrum. For many island groups, comparative smallness and remoteness help explain why many island societies are relatively impoverished, as measured by economic yardsticks, and therefore considered more in need than others of external assistance for adapting to future climate change (Betzold, 2015; Robinson, 2017; Nunn \& Kumar, 2018).

There is ample evidence that recent climate change is causing or amplifying livelihood challenges for many island inhabitants. This ranges from issues of water security (Belmar, McNamara, \& Morrison, 2016), unprecedentedly strong tropicalcyclone impacts (Cinco et al., 2016; Walsh et al., 2016), shoreline erosion and lowland flooding (Nunn, 2013; Betzold \& Mohamed, 2017), to coastal-settlement relocation (Gharbaoui \& Blocher, 2016; Charan, Kaur, \& Singh, 2017). Prognoses for island futures highlight the mismatch (as elsewhere) between the magnitude of projected impacts and the insufficiency of preparedness of island societies (Nunn, 2010; Khan \& Amelie, 2015) as well as the likelihood that entire islands, even whole island groups/countries, may be rendered uninhabitable within a few decades (Dickinson, 2009; Odalen, 2014; Schulte, Dridge, \& Hudgins, 2015).

Most solutions adopted for climate-change adaptation in island contexts have been short-term, reflecting both the culturally grounded preferences of many islanders and their dependence on time-limited (aid) funding assistance (Nunn, 2009). The emphasis on short-term interventions will inevitably lead to an amplification of the magnitude of livelihood challenges for many island communities by the mid-21 st century when both the pace of sea-level rise (and other manifestations of climate change) will likely have increased and the amount of external funding available for adaptation will likely have dropped significantly as donor nations divert funds towards the increasing costs of their own adaptation (Brown, Daigneault, \& Gawith, 2017; Travis, Smith, \& Yohe, 2018; Nunn \& Kumar 2019a). 
Given this situation, the need for a long-term fundamental reconfiguration of livelihoods on many islands - especially those where coastal subsistence dominates - seems clear. The most discussed manifestation of such 'transformational' adaptation in many island contexts in recent years has been relocation of vulnerable communities to less-vulnerable places (McNamara \& Jacot des Combes, 2015; Jamero et al., 2017). Transformational change integrates adaptations at magnified scales or intensity, those that potentially shift locations and/or transform places, as well as those that are new to a particular region and resource system (Kates, Travis, \& Wilbanks, 2012). Section 2 reviews the key challenges of climate-change adaptation in island contexts while Section 3 explains why this has often failed in recent decades. Section 4 makes the case for better aligning adaptation needs and interventions, arguing for the acceptance of the necessity of transformational change, while Section 5 discusses how this might best be driven.

\section{Adaptation to climate change in island contexts}

Most small islands considered in climate-change studies are part of Small Island Developing States (SIDS) but this chapter includes others that may be neither 'developing' nor part of independent island states. The heterogeneity of such islands complicates discussion of issues like their exposure to climate change. Indeed, it has been charged that the separation of islands (and island societies) from other inhabited landmasses reflects an inability to understand the diversity of island contexts (Stratford, 2008; Baldacchino, 2018); in other words, islands are often regarded as 'others' rather than a coherent category. It is clear that both the physical and socio-economic diversity of islands is something that should be acknowledged in any discussion of their commonalities. Islands may be comparatively large or high - two factors that unquestionably influence their vulnerability to climate change (Nunn, Kumar, Eliot, \& McLean, 2016; Kumar, Eliot, Nunn, Stul, \& McLean, 2018). Yet islands may also be 'developed', often close to (even part of) continental nations, or 'developing', typically more distant from continental shores and part of one of the groups of SIDS.

Notwithstanding this, the commonalities of islands justify the development of solutions for climate-linked stressors which are generally distinct from those developed for continental-coastal contexts. These commonalities across islands may be referred to as 'islandness' (Pelling \& Uitto, 2001). For Kelman (2018), there are three main sources of devastation for SIDS: sea-level rise, ocean acidification, and changes to ecosystems (driven by temperature and rainfall changes) that disrupt food and water supplies. For more than three decades, sea-level rise has been recognized as the principal climate-linked stressor of future island livelihoods, both subsistence and non-subsistence, although there have been periodic reminders of the importance of other associated stressors, largely those related to natural disasters. For this reason, most vulnerability assessments of islands have focused on 
their coasts - unarguably the most exposed parts - sometimes to the exclusion of their other inhabited or economically-important parts (Wang et al., 2017; Moffitt \& Kumar, 2018).

Island coasts are exposed to the effects of sea-level rise and all its attendant consequences, primarily shoreline erosion, lowland flooding, and groundwater salinization. The universal response options - accommodation, protection, or retreat - encapsulate island diversity. For example, along island coasts where resources are available to construct and - most importantly - maintain appropriately designed artificial shoreline-protection structures, 'protection' appears to be the sensible mid-term option although, as elsewhere, it is doubtful this can be sustained indefinitely. Yet commonly along eroding coasts in 'developing' island contexts, such structures are also fated to collapse and disrupt, invariably marked by the degradation of structures (linked to an inability to maintain them) and irreversible changes to nearshore sediment-water dynamics that increase vulnerability rather than reduce it (Kench, 2012; Betzold, 2015; Magnan \& Duvat, 2018; Nunn \& Kumar, 2018). It seems clear that 'soft' shoreline-protection' ${ }^{1}$ solutions like mangrove replanting are likely to be more effective and sustainable in such situations (Gilman et al., 2006; see also Duvat \& Magnan, this volume).

Most information about climate change available to people living on islands is generic/global. The lack of localization is acknowledged as a compounding issue for adaptation in other geographical contexts (Forsyth, 2013; Ireland \& McKinnon, 2013) but is doubly so on islands where the historical tendency to treat them as 'miniature continents' spawned a legacy of inappropriate environmental management interventions (Doumenge, 1987; Gillis, 2014). In addition to localized knowledge, it is important for those involved in environmental governance on islands to be aware of their unique attributes, ranging from the changeability of reef-island form to the importance of offshore ecosystems in maintaining sediment supply to island beaches (Oost et al., 2012; Fujita et al., 2014).

Beyond exposure, underlying socio-economic and development challenges influence the impacts of climate change in island contexts, and as such remain a major concern in these places (Kelman, 2014). These challenges are often amplified by economic instability in these island contexts (Encontre, 1999; Pelling \& Uitto, 2001). This is due to their limited capacity to exploit trading and other opportunities, reliance on only a few export products, limited ability to enjoy economies of scale, and significantly high unit costs for producing and marketing key commodities (Deidda, 2016). Another key factor influencing the sensitivity of islands to climate risks is the increasing challenges of high concentrations of populations and critical infrastructure in urban areas. Similar to rapid urbanization in other developing countries, this can often result in overcrowding, populations

\footnotetext{
${ }^{1}$ Soft solutions for shoreline protection are generally nature-based and often comprise revegetation. Hard solutions imply the presence of artificial shoreline structures that often fundamentally alter the process dynamics and form of coasts.
} 
living in precarious environments, and greater pressures on resources and ecosystems (Bryant-Tokalau, 2018).

Adaptive capacity challenges in islands are pervasive. Betzold (2015) makes the case that islands' low adaptive capacity is typically driven by a lack of resources, institutional barriers, and inadequate awareness. Nunn (2013) has argued that the adaptive capacity of local communities has been further diminished because of a growing dependence on donor agendas and funding. Institutional challenges often arise from sub-optimal coordination between government tiers and inadequate understanding of climate-change challenges among local leaders. Spiritual beliefs, the influence of religious institutions, and a psychological distancing of climate change can all have significant effects on local communities' sense of urgency about and perceptions of climate change risk (Arnall \& Kothari, 2015; Nunn, Mulgrew, Scott-Parker, et al. 2016).

One of the most profound challenges faced by today's island dwellers with respect to climate change is the widespread inadequacy of institutional responses. For islands within continental jurisdictions, a common complaint is that their geographically marginal nature frequently translates into marginalization in the policy and action contexts (Beer, 2004; Armstrong \& Read, 2006). ${ }^{2}$ Calls to establish a level of self-determination appropriate to island-specific environmental governance have generally gone unheeded (Stratford, 2008; Pittman, Armitage, Alexander, Campbell, \& Alleyne, 2015). For islands that are part of independent SIDS, insufficient resources often hinder the development and enforcement of appropriate policy (Kelman, 2014). In archipelagic groups, most funds for climate-change adaptation flow into small 'core' areas where awareness is consequently greater, a situation that often leaves a massive 'periphery' where people's responses tend to be more autonomous and less informed by global knowledge (Nunn, Aalbersberg, Lata, \& Gwilliam, 2014; Nunn \& Kumar, 2018). Recent research shows that the value of traditional knowledge and coping capacity in such peripheral locations is likely to help their peoples better adapt to future climate change (Maru, Stafford Smith, Sparrow, Pinho, \& Dube, 2014; Janif et al., 2016; Remling \& Veitayaki, 2016; Mackay et al., 2018; Nunn \& Kumar 2019b).

The diversity of islander views is rarely articulated on international stages. For different reasons, islanders' views about climate change are often represented by others, be they the representatives of largely continental jurisdictions (of which islands are only a small part) or designated larger-country representatives speaking on behalf of smaller (island) ones; Pacific SIDS have a history of the latter situation that some regret (Kelman, 2010). While representatives of many SIDS are vocal in international meetings, epitomised by Fiji chairing COP-23 (2017) in Bonn, the loudest voices are mostly those of their leaders who are apt to emphasize their

\footnotetext{
${ }^{2}$ A recent review makes the opposite point, namely that "islands tend to enjoy higher levels of constitutional recognition and jurisdiction than mainland territories ... [a] testament to opportunities arising from the conjuncture of geography and history" (Warrington \& Milne, 2018, p. 176).
} 
nations' need of adaptation funding rather than their people's need to adapt (Baldacchino, 2018). ${ }^{3}$

\section{Why recent adaptation on islands largely failed}

After more than thirty years, there are very few examples of externally driven community-level interventions for climate-change adaptations in poorer ('developing') island contexts that have been both effective and sustained. While this failure is rarely admitted explicitly (Piggott-McKellar, McNamara, Nunn, \& Watson, 2019), it is manifest from considering the lack of awareness and indecision that typically characterises environmental governance in most such situations - something that would not be expected had adaptation been effectively mainstreamed (Patt \& Schroter, 2008; Paton \& Fairbairn-Dunlop, 2010; Chandra \& Gaganis, 2016; Scott-Parker \& Kumar, 2018). In richer ('developed') island contexts, the current situation is understandably different, with many such coastlines - from Oahu (Hawaii) to Singapore - marked by costly coastal-engineering solutions that armour exposed coasts (Romine \& Fletcher, 2012; Chan, Chuah, Ziegler, Dabrowski, \& Varis, 2018). Yet notwithstanding the availability of resources, the tendency of decision-makers to 'protect' island shorelines to allow a continuation of coastal living - rather than consider relocation - speaks to both the almostuniversal desire of coastal dwellers to remain living on coasts and to the short-term political/societal gains associated with implementing a 'protect' strategy.

Many of today's coastal dwellers do not appreciate the long-term changeability of the places they live, having invested significantly in coastal places and consequently resisting prognoses suggesting these may become uninhabitable in the foreseeable future (Costas, Ferreira, \& Martinez, 2015). For many coastal societies - and their leaders - climate-change denialism and the associated popularity of short-term fixes (like 'protect') to what are often portrayed as temporary problems (like shoreline erosion and lowland flooding) make perfect sense. Yet as has been amply documented in all island contexts, such interventions may be effective in the short term but are rarely sustainable in the sense either that they can remain effective without periodic injections of (scant) maintenance funding or that they do not create new problems for island coastal dwellers. For example, in the reef (atoll) islands of the Maldives artificial shoreline-protection structures "have a high failure rate ... [and are] implicated in the generation of additional island instability problems" (Kench, 2012, p. 168). In the case of such islands, which commonly rise only 2-3 $\mathrm{m}$ above mean sea level, the only way to sustain coastal/island living in the

\footnotetext{
3 This point reflects the tendency of many national leaders to portray their countries as needing money to address climate change, an approach that has undoubtedly increased revenue to many such countries over the past few decades. Yet, given that little of that funding has filtered down to most rural communities struggling to cope with the effects of climate change, it is reasonable to infer that community adaptation needs are not prioritised for funding in most cases.
} 


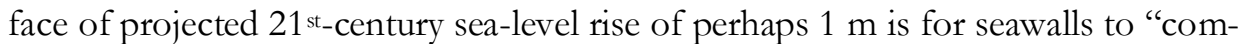
pletely surround the islands" (Cooper \& Pilkey, 2012, p. xiii), something that might be achievable in richer/iconic island contexts but clearly not in all.

Choosing the 'protect' response in island contexts also often produces unanticipated impacts on the livelihoods of coastal people. These impacts range from beach narrowing/loss (Jackson, Bush, \& Neal, 2012; Romine \& Fletcher, 2012) to nearshore ecosystem degradation and biodiversity loss, something that threatens food security for coastal dwellers in rural locations in SIDS (Bell et al., 2009; Bellard, Leclerc, \& Courchamp, 2014). In most island contexts, there is rarely sufficient data to adequately inform the design and positioning of 'protective' structures, many of which with hindsight can be seen as having promised benefits that have not eventuated (Duvat, Magnan, \& Pouget, 2013; Beyerl, Mieg, \& Weber, 2018; Nunn \& Kumar, 2018).

While wealthier islands are likely to be able to find the funds in the future to sustain adaptation along coasts - whether involving accommodation, protection, or retreat - the situation is likely to become more challenging for people occupying the coasts of poorer islands including many SIDS. It is therefore imperative to understand the reasons why recent adaptation efforts along poorer-island coasts have largely failed - and what needs to happen to reverse this situation within the next decade or so.

The background to this situation is that the national governments of most (archipelagic) SIDS do not usually have the capacity (human or financial) to effectively engage all rural communities for the purposes of sidestream (not mainstream) issues like climate-change adaptation. This means that for such challenges, and the environmental governance context they fall within, communities are effectively required to make their own decisions (Nunn et al., 2014). Most such decisions are made by people with little formal education, informed largely by (perceived) precedent and analogy, and typically short-term. For most people in such communities, a belief in the security of coastal living is divinely supported and the idea of relocation consequently almost unthinkable, "barely conceivable at present" (Kempf, 2012, p. 250).

The ways in which community-level decision-makers in such places are influenced is also important to understand (Scott-Parker et al., 2017; Beyerl et al., 2018). Many such 'persons of influence' in rural SIDS communities have travelled to capital cities where they observe artificial shoreline structures effectively protecting the coast. These observations strengthen their belief in the efficacy of 'protect' responses and explain why many rural communities place so much faith in artificial structures of this kind (Nunn, 2013). Yet capital-city shoreline protection (and its ongoing maintenance) in SIDS is often aid-funded and aid-sustained, hardly therefore representative of the capacity of a particular island government. In this sense, it sends a misleading message to rural communities who often raise scarce cash to build a seawall that is opened with great fanfare, only to collapse 18-24 months later whereupon funds for its (less glamorous) repair are often inadequate, leading 
to the situation where Pacific Island coasts are said to be "littered with the remains of collapsed and ineffective seawalls" (Dean, Green, \& Nunn, 2016, p. 85).

So while it is clear that a sensible goal is the more effective empowerment of 'persons of influence' in rural island communities to make decisions about how that community might withstand the effects of long-term climate change, the issue is why has this not yet happened. There are many reasons but those that seem common to most such communities revolve around issues of communication and messaging, dependency and autonomy, long-term versus short-term planning horizons, and uncertainty and anxiety; each is discussed separately below.

\subsection{Communication and messaging}

Recent research stresses the need for effective communication in climate-change adaptation strategies (Moser, 2014; Rudiak-Gould, 2014). External interventions in poorer-country rural island communities run many risks in this regard. One is that interventions are generally designed and premised from the point of view of the intervenor's society - one that is invariably non-communal and secular and which unquestioningly privileges (Western) science and the written word. In sharp contrast, many target communities are those where communal decision-making is usual; where decisions are invariably parsed through spiritual filters ('What does God want us to do?'), and influenced more by spiritual than secular authorities; where hardly anyone has more respect for 'Western' scientific understanding over the 'traditional' knowledge that has accumulated in the community over generations; and where orality is more common than literacy as a way of communicating or reviewing important information (Paton \& Fairbairn-Dunlop, 2010; Nunn, Mulgrew, Scott-Parker, et al., 2016b; Nunn \& Kumar, 2018).

External agents (like donor countries and international organisations) that sponsor interventions for climate-change adaptation in such rural communities have been reluctant to recognise that such 'barriers' have two sides. Those that are perceived from the 'inside' are as important to break down as those - more often discussed (Biesbroek, Klostermann, \& Termeer, 2013; Kuruppu \& Willie, 2015; Mackay et al., 2018) - that appear to exist from the outside. So commonly does it appear that external agents of this kind are reluctant to learn how to identify and demolish these barriers that one might reasonably question whether in fact they wish to - or whether the process of funding interventions is in itself considered adequate reward.

\subsection{Dependency and autonomy}

Many SIDS exhibit high levels of dependency on their (richer) donor partners and international funding organisations for underwriting the costs of non-revenue generating activities like climate-change adaptation. This has long been recognised as unfortunate because sustained adaptation requires island nations to 'own' the chal- 
lenge of climate change (Barnett, 2008; Nunn, 2009). Dependency at the national level in many SIDS and the associated availability of adaptation funding has led to many national leaders becoming fixated on accessing this funding by declaring their nations to be uncommonly needy. While this may be true, the fact that so little adaptation funding filters down from governments to communities is creating a divide where larger-scale projects - often incidentally associated with new prospects for revenue generation - are funded while the increasingly parlous situation in which many subsistence (coastal) communities find themselves is not being effectively addressed. To some extent, non-governmental organisations (NGOs) are filling this gap but their capacity is commonly insufficient to meet demand. ${ }^{4}$

Many rural communities in SIDS (and similar peripheral-island contexts) are also focused on 'development' activities, especially those which enhance cash revenues through increased production or value-added processing (Jaini, Advani, Shanker, Oommen, \& Namboothri, 2018; Singh-Peterson \& Iranacolaivalu, 2018). This focus often implicitly excludes the effects of environmental shocks like natural disasters or longer-onset climate-driven changes like sea-level rise, being premised on the assumption that novel production systems which drive livelihood improvement underwrite resilience-building. The upshot of this view is that community support for many such initiatives often collapses after such shocks or is only incompletely restored (Bunce, Mee, Rodwell, \& Gibb, 2009; Mohan \& Strobl, 2017).

It is important to discuss how such communities might be empowered to adapt autonomously, or at least in cooperation with others in the same district. While aspects of this are covered in discussions about the advantages of 'bottomup' over 'top-down' initiatives in such situations - especially the value of localisation and ownership of solutions (Mertz, Bruun, Fog, Rasmussen, \& Agergaard, 2010; Betzold, 2015) - the nuances of island contexts are also important to consider.

\subsection{Long-term versus short-term planning horizons}

In subsistence communities, which routinely acquire most of the food they consume from the surrounding environment, there is understandably a focus on shortterm sustainability of food sources. Most planning is annual in such SIDS communities, a mixture of strategies at both community and family levels. Many such communities have reserve foods that are not usually consumed but may be so in times of exigency, such as after natural disasters (Johnston, 2014; McNamara \& Prasad, 2014). In generally more isolated/smaller island contexts, strategies for conserving marine food sources (in particular) evolved over many generations and

\footnotetext{
${ }^{4}$ Non-governmental organisations (NGOs) are active in many aspects of climate-change adaptation in the Pacific Islands, often filling voids that governments are unable to address. These aspects include a focus on peripheral (outer-island) communities, on livelihood sustainability within (largely) subsistence-based communities, and ways of income generation appropriate to these contexts.
} 
involved periodically designating particular places off-limits (taboo) in order to allow their food-producing potential to be renewed (Johannes, 2002; Foale, Cohen, Januchowski-Hartley, Wenger, \& Macintyre, 2011).

Few island communities are today wholly subsistence-based. Mass importation of cheap (often nutritionally poor) foods has allowed their penetration into the remotest island communities, a tendency that has eroded traditional subsistencebased strategies (Campbell, 2015).

\subsection{Uncertainty and anxiety}

Scientific uncertainty is often difficult to explain to non-specialists, something occasionally hailed as a justification for inaction with respect to climate-change risk planning (Barnett, 2001). For many stakeholders in poorer-island contexts, the value of scientific projections is not readily acknowledged. Often informal projections, typically based on remembered precedent or spiritual beliefs, are valued far higher in such contexts. And while this often gives such communities some comfort that builds psychological resilience (Farbotko \& Lazrus, 2012), this is often simultaneously demolished by the ubiquitous media reports about climate change that, in the Pacific Islands, tend to focus on newsworthy extreme scenarios (unsupported by scientific consensus) rather than more accurate mainstream reports (Robie, 2014; Dreher \& Voyer, 2015; Scott-Parker et al., 2017).

Anxiety about slow-onset climate change is difficult to document formally (Bourque \& Willox, 2014). This is especially true both in communal societies (like those on many such islands) and by outsiders who inevitably lack sufficient cultural understanding to identify the presence or otherwise of such anxiety; a recent debate on the framing of climate change by fishers in the Lofoten Islands (Norway) exemplifies the latter point (Dannevig \& Hovelsrud, 2016; Bercht, 2017). In many places, the situation is clearer for (rapid-onset) natural disasters, where traumatised survivors have often benefited from counselling, although in poorer-island contexts comparatively little has been formally reported (Sattler, 2017).

A key issue is the possibility and the practicality of relocation of coastal communities from vulnerable locations to less-vulnerable ones. In addition to the reluctance of many such communities to consider relocating within the same island, the issue of land tenure is often influential. Many coastal/lowland communities in SIDS hold title to the land they occupy yet not to places to which they might relocate. This is a problem because such communities, often being only partly within the cash economy, lack the means to lease land from others who expect to be paid for this. In addition, in-island relocation often means loss of identity, associated with separation from place, as well as a more pragmatic reconfiguration of subsistence livelihoods. These complex and difficult issues are discussed further in the following section.

Such problems may multiply when the issue of relocation from one island likely to be rendered uninhabitable by sea-level rise - to another less vulnerable is 
considered. In addition to the feared cultural attrition and loss of identity involved in resettlement, there are inevitably concerns about mixing with longer-term residents elsewhere. There are historical precedents in island contexts that show such concerns are justified, including the $20^{\text {th }}$-century relocation of Phoenix Islanders (in what is now Kiribati) to parts of what is now Solomon Islands (Donner, 2015) and the more recent relocation of Carteret Islanders to Bougainville in Papua New Guinea (Edwards, 2013; Connell, 2016). For such reasons, the prospective relocation of people from Kiribati to Fiji is being discussed circumspectly (Hermann \& Kempf, 2017; see also Hermann \& Kempf, this volume).

\section{Aligning adaptation needs and interventions: the underpinnings of transformational change}

Transformational change can help reduce the root causes of climate change vulnerability. Two key factors are identified in an islands context. First, frameworks about risk management should incorporate transformational adaptation and, second, research that grows the existing range of innovative transformational adaptations should be conducted. At the community level, supportive social contexts combined with incentives and the availability of appropriate and understandable options, and the availability of resources for action and leadership also influence the initiation and sustainability of such change (Kates et al., 2012).

There are numerous things that should be changed - or done better - in order for climate-change adaptation projects on islands to become more effective, sustainable, and, ultimately, transformational. Paramount among these is the need to recognise islands as environments that contrast with those of continents, meaning their environments and societies are often quite different. Especially yet not exclusively in SIDS, there are other issues (see below) that should be addressed before adaptation is likely to become successful in such terms. Behind all these concerns lies the issue of process, specifically the need to replace the commonly one-way direction of adaptation (intervention) efforts with genuine interaction in which both external agents and target communities/groups have at least equal say in the nature, design, and implementation of adaptation pathways (Mercer, DomineyHowes, Kelman, \& Lloyd, 2007).

This section asks whether we are doing the right kinds of things to prepare island dwellers for the challenges that future climate change will pose to the ways they live. Most projections suggest that the main climate-driven stressors of contemporary island life - temperature rise and sea-level rise - will continue at least for the next few decades and likely accelerate (Figure 1). In those island realms affected by tropical cyclones (hurricanes) it is likely that, while the frequency of these will decrease in the future, their average intensity will increase (Walsh et al., 2016); storms like Tropical Cyclone Pam (Vanuatu, 2015) and Severe Tropical Cyclone Winston (Fiji, 2016) may become more usual. 

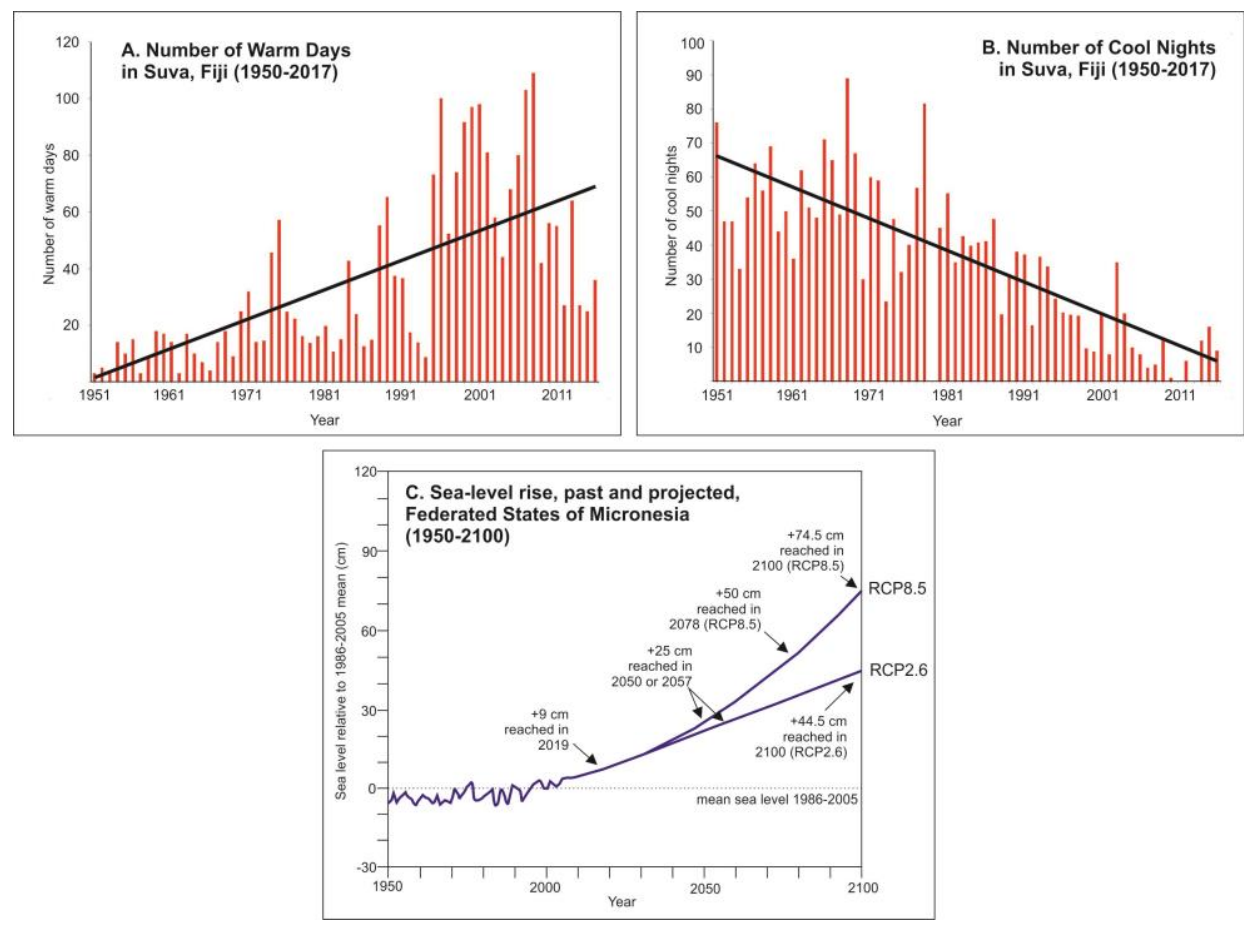

Figure 1: Examples of the evidence for climate change in island countries

$A$ and B. Changes (1951-2017) in the numbers of warm days and cool nights in Suva (Fiji) showing the effects of global warming here. These trends are projected to continue. Data from Fiji Meteorological Service, provided by Simon McGree at the Australian Bureau of Meteorology.

C. Recent and projected (future) sea-level rise in the Federated States of Micronesia where the rate of sea-level rise is currently 2-3 times the global average (Becker et al., 2012). Projections are based on those of IPCC AR5 (2013-2014) and are considered conservative, more recent studies suggesting sea level in 2100 will likely be more than $1 \mathrm{~m}$ above present (e.g. Mengel et al., 2016). Given that emissions are following Representative Concentration Pathway (RCP) 8.5 closest, it is likely that the rate of sea-level rise will accelerate over the next few decades. Graph adapted from BOM (2014).

As in many other places, especially coastal ones, the multifarious impacts of temperature and sea-level rise and increased tropical-cyclone intensity will inevitably result in situations being reached by (at least) mid-century where most (coastaldwelling) island people will be unable to continue living as they do currently. Given the experience of the past thirty years or so and the focus on short-term responses, it seems unlikely that the necessary adaptation to allow these people to be living the lives to which they aspire in or near such locations can be achieved incrementally (Kates et al., 2012). This is not to say that incremental change should never be 
attempted. Patrick D. Nunn's recent research with the Navunievu community in coastal Vanua Levu Island in Fiji found that, in response to concern about sealevel rise and its effects on the village, local leaders have decreed that newly married couples must build their houses inland/upslope rather than on the low-lying coastal plain. After some decades, such adaptation may see most of the village relocated through autonomous and low-cost incremental action.

The alternative to incremental adaptation is transformational adaptation involving radical change intended to climate-proof community infrastructure and livelihoods as far as this is ever possible. In island contexts, transformational adaptation to future climate change invariably involves relocation of vulnerable communities and infrastructure to less-vulnerable locations, a process that may be accompanied by livelihood reconfiguration, and economic and cultural changes that may also be transformative (Piggott-McKellar, McNamara, Nunn, \& Sekinini 2019). For (coastal) communities anywhere, this is not a trivial issue; on islands, there are particular concerns. Most islanders live along island coasts where they can readily access the greatest diversity of food resources and where interaction with other people is easiest; indeed on many islands, interior populations have only ever increased during times of conflict (Nunn, 2007). For this reason, not only are many island interiors/hinterlands comparatively sparsely inhabited but they also currently lack the infrastructure needed to service the needs of large numbers of coastal relocatees.

The issues around relocation are slowly becoming the subject of mainstream science-informed discussions, yet understandably are commonly focused on the world's most densely-populated coastal districts (Collins, Jones, Nguyen, \& Stanton, 2017). On islands, there are growing numbers of precedents for future relocation that have been studied, particularly with a view to understanding the particular nuances of inter-island population movements and, more generally, lessons learned and errors made (Connell, 2012; Donner, 2015).

For example, it seems clear that concerns about 'loss of place' often dominate negotiations for relocation, whether in richer contexts where people will lose money and perhaps expect compensatory payments or in subsistence contexts where people have strong intangible connections to land that require culturally grounded methods of severance and processes of working through loss and grief (Head, 2016). The same dynamic exists in both cases.

Similar parallels exist with 'acquisition of place'. In richer contexts, money (perhaps compensation, perhaps top-down sponsored investments) is used to create places to which people might be relocated; land purchase avoids many issues around lack of relocatee rights or unwelcomeness. In poorer contexts, where money to compensate relocatees or purchase land elsewhere for them may be insufficient, successful negotiations need to stress exigency (the urgent need to move), demonstrate extra-community support (from parties like religious organisations that are respected by all), and persuade inland landowning groups - preferably the 
same cultural groups - to accept relocatees on the grounds that they have been unfairly and disproportionately impacted.

There are models of relocation process to follow (see following section). These involve the 'establishment of place' - the preparation of sites for relocation. In richer contexts, this involves the development of infrastructure and utilities intended to attract individual households and businesses from vulnerable locations. In subsistence contexts, this involves the allocation of land (and sea) from which to obtain food and places for the construction of dwellings/community as well as important intangible resources (e.g. memorialisation and access to ancestral lands) where the cultural identity of relocatees can be preserved.

None of the above can be effective and sustainable unless vulnerable people's needs are aligned with the agendas of those who have the power to drive the necessary transformational adaptation. At present, in almost every island situation, most climate-change adaptation is undertaken to meet short-term goals rather than the longer-term ones implicit in climate changes like those shown in Figure 1. A fundamental shift in the ways we conceive and plan for environmental risk is needed (Martin, Maris, \& Simberloff, 2016). The next section discusses how this might happen and who might drive it.

\section{The way forward in island contexts: driving transformational change}

Enabling transformational adaptation - especially relocation - in island contexts is easier to plan than to implement successfully. Relocation is complex and difficult, and is rarely what vulnerable local communities desire. This applies to islands in both richer and poorer countries. One of the principal challenges with relocation, identified above, is negotiating people's 'attachment to place' enough to persuade those people that they should move to other (less vulnerable) locations. The other major challenges are around 'acquisition of place' that involves both the identification and preparedness of (new) places for relocatees and the ongoing support of those occupying/owning the areas where these places are located.

Relocation within higher islands ${ }^{5}$ requires the involvement of state actors at both national and subnational levels and - at least in poorer contexts - some contribution to the process by non-state actors, from NGOs to donor partners and international organisations charged with global oversight of adaptation. ${ }^{6}$ This section first considers how such transformational adaptation might best be carried out on islands and then who should best drive this process.

\footnotetext{
${ }^{5}$ Defined as those islands where the highest point is at least $30 \mathrm{~m}$ above sea level (see Nunn, Kumar, Eliot, \& McLean, 2016). On such islands, it is generally assumed that people can be relocated within the same island; on lower islands, relocation may be offshore.

${ }^{6}$ Principal among such organisations is the Adaptation Fund which, since it was set up in 2010, has committed US $\$ 477$ million to 76 mostly-'developing' countries to counter the effects of climate change (www.adaptation-fund.org).
} 


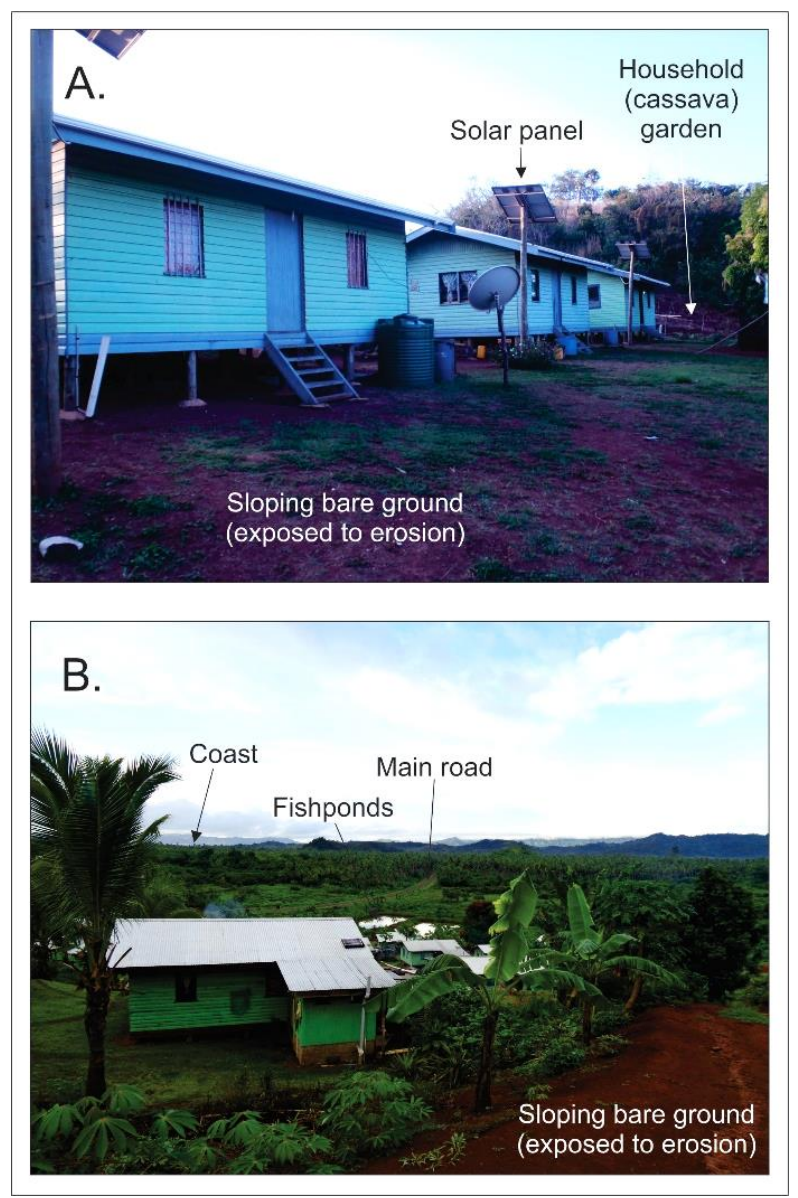

Figure 2: Relocated communities on Vanua Levu Island in Fiji

A. View of Korovou on Yadua Island (Bua) to which 19 families from neighbouring (coastal-lowland) Denimanu Village were relocated in 2016. Note the standard house design, which came with the provision of solar panels, water tanks, and flush toilets/showers that were not standard in the previous houses. Although only five minutes walk from the sea, Korovou reaches $35 \mathrm{~m}$ above sea level and is closer to most food gardens than Denimanu. Photo by Patrick Nunn.

B. View of Kenani (Cakaudrove) to which all residents from the (coastal-lowland) village of Vunidogoloa were relocated in 2014 . Since the new village is more than an hour's walk from the sea, fishponds were constructed to partly replace seafoods in the residents' diet. Access to the main road has opened up possibilities for commerce. Much of the ground is composed of thick orange regolith which is liable to erosion and sometimes landsliding after its vegetation cover has been cleared, as it was for the construction of level house sites in this steepland terrain. Photo by Annah Piggott-McKellar, used with permission. 
The first step in transformational adaptation involving relocation on higher islands is to identify vulnerable communities and the time frames over which they need to be relocated. It is essential this process be driven in partnership with affected local communities. For relocation to be even remotely successful, then it needs to be not only unforced but also led and governed by those affected. The second step involves identifying the possible places to which these communities might relocate, including the advantages and disadvantages of each, again in an inclusive and transparent manner whereby affected communities are helping make decisions. The third step is to estimate the minimum cost of the preferred relocation which may include negotiable/indirect costs like compensation for loss and damage. Human rights, dignity, equity, and sustainability are all concepts that need to be closely considered during these 'planning' stages (Henly-Shepard, McNamara, \& Bronen, 2018).

The next steps involve 'implementation of relocation' and will inevitably vary depending on the particular situation and whether it is suitable for incremental or wholesale relocation (Figure 2). Incremental pathways involve the initial (disproportionately assisted) movement of either the most-vulnerable or iconic elements of a community in the expectation that this would encourage later (disproportionately less assisted) and more autonomous relocation by other elements of that community. In contrast, 'wholesale relocation', which is more costly and often topdown, involves the relocation of an entire community at one time.

Recent relocations in Fiji exemplify both cases (Piggott-McKellar, McNamara, Nunn, \& Sekinini 2019). The most exposed households (19 or 34\%) in the Fijian community of Denimanu (Yadua Island, Bua) to be impacted by a combination of sea-level rise and storm surge during Tropical Cyclone Evan in 2012 were relocated in 2016 to a new site (Korovou) upslope (Figure 2, panel A). The cost of relocation was borne entirely by the Government of Fiji, something lauded by the affected people, some of whom yet regret the lack of contribution from Fiji's wealthier donor partners and doubt the long-term viability of the relocation. This is an example of incremental relocation in the sense that only a portion of the Denimanu community was relocated and there is currently discussion amongst the remainder about when and where they too might need relocation, given the sea-level rise they have observed since 2012 (Martin, Nunn, Leon, \& Tindale, 2018).7

A wholesale relocation driven by the progressive effects of sea-level rise is that of Vunidogoloa (Vanua Levu Island, Cakaudrove). Problems were becoming acute for people in the coastal village of Vunidogoloa in 2006 so a request was made to the Fiji Government to be relocated; all $\sim 140$ inhabitants moved to the new inland upslope site (Kenani) in January 2014 (McNamara \& Jacot des Combes, 2015; Charan, Kaur, \& Singh, 2017). The move was thoroughly planned, involved extensive community consultation and support, and was to land that the Vunidogoloa

\footnotetext{
${ }^{7}$ Sea level is rising along Fiji's coasts at a rate of about $5.5 \mathrm{~mm} /$ year, significantly higher than the global average of about $3.2 \mathrm{~mm}$ /year (BOM, 2014; Dangendorf et al., 2017).
} 
people already owned (Figure 2, panel B). The costs of the move incurred by the Fiji Government were partly offset by the sale of forest growing on and around the new site.

Post-relocation monitoring and evaluation are also an important part of the process of transformational change, not least in order to identify lessons learned that might help improve comparable future relocations but also to ensure that any challenges related to the relocation are resolved as they arise.

The process of relocation outlined above needs to be driven by local communities but also requires the involvement of actors external to affected communities, not least to underwrite the costs of preparing new places for relocatees to live. These costs might involve landscape modification, the provision of basic infrastructure and utilities, as well as the cost of new houses. While relocation remains a comparatively novel use of external (aid) funding, it may remain attractive for external support but, as it becomes more commonplace, so such costs may come to be regarded as something island governments should be funding. It is therefore important, especially in SIDS, that pathways for relocation are developed which minimise the need for external funding and maximise the absorption of costs by affected communities and households. Diverting funds from short-term adaptation responses (like 'protect' and 'accommodate'), which are unlikely to be sustainable on decadal scales, towards longer-term transformational responses would help underwrite the costs of these.

Transformational adaptation in island contexts does not only mean relocation. In many such places, it also means that livelihoods of the affected people need to change; for example, people accustomed to subsisting significantly from nearshore marine foods may find themselves in places where these are less easy to access so need to be substituted by other, comparable sources of food such as fishponds (see Figure 2, panel B). Transformational adaptation also provides opportunities for quality-of-life improvement, whether this refers to subsistence livelihoods and food security, or to human development indicators such as health or education, or more reliable transport networks.

\section{Conclusion}

Island people face many challenges from climate change. To date, the vast majority of efforts to address these challenges have been reactive and have favoured shortterm goals rather than the long-term ones that are in line with current climatechange projections. There is a clear need for transformational adaptation in island contexts where, owing to their singular attributes, this need is more pressing than elsewhere. For example, if sea-level rise in the western Pacific continues at its current rates (two to four times the global average; Becker et al., 2012), then increasing numbers of island-coastal communities are likely to be rendered unviable within the next ten to twenty years. 
Relocation of vulnerable coastal communities to less vulnerable locations on islands is hampered by their geography and by a dependency of many island jurisdictions on funding from elsewhere for such non-revenue generating activities. Transformational adaptation needs to occur within national institutions, which should take ownership of climate-change issues, ensure their localisation, and help empower subnational (and community-level) decision-makers to drive and sustain them.

While pathways for transformational adaptation have been studied and are proposed anew in this paper, there is still a significant challenge involved in persuading governments, and then ultimately the island communities which will be affected, of the need for such adaptations. This makes sense. It is not easy for anyone to suggest such transformations when there is significant risk to identity, livelihoods, and culture, real or perceived. Yet there needs to be pragmatic and realistic opportunities for weighing up the benefits of long-term anticipatory adaptation, such as relocation, rather than planning for more immediately comforting and cheaper short-term goals.

\section{Acknowledgements}

Many ideas in this paper have been drawn from the results of recent research into the nature and efficacy of climate change adaptation in Pacific Island contexts, funded by the Australian Research Council (ARC) through Linkage Grant LP160100941 (to KM and PN) and the Asia-Pacific Network for Global Change Research (APN) through grant CRRP2015-FP02 (to PN).

\section{Bibliography}

Armstrong, H. W., \& Read, R. (2006). Geographical 'handicaps' and small states: Some implications for the Pacific from a global perspective. Asia Pacific Viewpoint, 47(1), 79-92.

Arnall, A., \& Kothari, U. (2015). Challenging climate change and migration discourse: Different understandings of timescale and temporality in the Maldives. Global Environmental Change, 31, 199-206.

Baldacchino, G. (2018). Seizing history: Development and non-climate change in Small Island Developing States. International Journal of Climate Change Strategies and Management, 10(2), 217-228.

Barnett, J. (2001). Adapting to climate change in Pacific Island Countries: The problem of uncertainty. World Development, 29(6), 977-993.

Barnett, J. (2008). The effect of aid on capacity to adapt to climate change: Insights from Niue. Political Science, 60(1), 31-45.

Barnett, J. (2017). The dilemmas of normalising losses from climate change: towards hope for Pacific atoll countries. Asia-Pacific Viewpoint, 58(1), 3-13. 
Becker, M., Meyssignac, B., Letetrel, C., Llovel, W., Cazenave, A., \& Delcroix, T. (2012). Sea level variations at tropical Pacific islands since 1950. Global and Planetary Change, 80-81(1), 85-98.

Beer, S. (2004). Information flow and peripherality in remote island areas of Scotland. Libri, 54(3), 148-157.

Bell, J. D., Kronen, M., Vunisea, A., Nash, W. J., Keeble, G., Demmke, A., . . . Andréfouët, S. (2009). Planning the use of fish for food security in the Pacific. Marine Policy, 33(1), 64-76.

Bellard, C., Leclerc, C., \& Courchamp, F. (2014). Impact of sea level rise on the 10 insular biodiversity hotspots. Global Ecology and Biogeography, 23(2), 203-212.

Belmar, Y. N., McNamara, K. E., \& Morrison, T. H. (2016). Water security in small island developing states: The limited utility of evolving governance paradigms. WIREs Water, 3(2), 181-193.

Bercht, A. L. (2017). No climate change salience in Lofoten fisheries? A comment on understanding the need for adaptation in natural resource-dependent communities. Climatic Change, 144(4), 565-572.

Betzold, C. (2015). Adapting to climate change in Small Island Developing States. Climatic Change, 133(3), 481-489.

Betzold, C., \& Mohamed, I. (2017). Seawalls as a response to coastal erosion and flooding: A case study from Grande Comore, Comoros (West Indian Ocean). Regional Environmental Change, 17(4), 1077-1087.

Beyerl, K., Mieg, H. A., \& Weber, E. (2018). Comparing perceived effects of climate-related environmental change and adaptation strategies for the Pacific small island states of Tuvalu, Samoa and Tonga. Island Studies Journal, 13(1), 25-44.

Biesbroek, G. R., Klostermann, J. E. M., Termeer, C. J. A. M., \& Kabat, P. (2013). On the nature of barriers to climate change adaptation. Regional Environmental Change, 13(5), 1119-1129.

BOM. (2014). Climate Variability, Extremes and Change in the Western Tropical Pacific: New Science and Updated Country Reports. Melboume.

Bourque, F., \& Willox, A. C. (2014). Climate change: The next challenge for public mental health? International Review of Psychiatry, 26(4), 415-422.

Brown, P., Daigneault, A., \& Gawith, D. (2017). Climate change and the economic impacts of flooding on Fiji. Climate and Development, 9(6), 493-504.

Bryant-Tokalau, J. (2018). Indigenous Pacific approaches to climate change. Cham, Switzerland: Palgrave.

Bunce, M., Mee, L., Rodwell, L. D., \& Gibb, R. (2009). Collapse and recovery in a remote small island-A tale of adaptive cycles or downward spirals? Global Environmental Change-Human and Policy Dimensions, 19(2), 213-226.

Campbell, J. R. (2015). Development, global change and traditional food security in Pacific Island countries. Regional Environmental Change, 15(7), 1313-1324.

Chan, F. K. S., Chuah, C. J., Ziegler, A. D., Dabrowski, M., \& Varis, O. (2018). Towards resilient flood risk management for Asian coastal cities: Lessons 
learned from Hong Kong and Singapore. Journal of Cleaner Production, 187, 576-589.

Chandra, A., \& Gaganis, P. (2016). Deconstructing vulnerability and adaptation in a coastal river basin ecosystem: A participatory analysis of flood risk in Nadi, Fiji Islands. Climate and Development, 8(3), 256-269.

Charan, D., Kaur, M., \& Singh, P. (2017). Customary land and climate change induced relocation - a case study of Vunidogoloa Village, Vanua Levu, Fiji. In W. L. Filho (Ed.), Climate Change Adaptation in Pacific Countries (pp. 19-33). Cham, Switzerland: Springer International Publishing.

Cinco, T. A., de Guzman, R. G., Ortiz, A. M. D., Delfino, R. J. P., Lasco, R. D., Hilario, F. D., ... Ares, E. D. (2016). Observed trends and impacts of tropical cyclones in the Philippines. International Journal of Climatology, 36(14), $4638-4650$.

Collins, N., Jones, S., Nguyen, T. H., \& Stanton, P. (2017). The contribution of human capital to a holistic response to climate change: Learning from and for the Mekong Delta, Vietnam. Asia Pacific Business Review, 23(2), 230-242.

Connell, J. (2012). Population resettlement in the Pacific: Lessons from a hazardous history? Australian Geographer, 43(2), 127-142.

Connell, J. (2016). Last days in the Carteret Islands? Climate change, livelihoods and migration on coral atolls. Asia Pacific Viewpoint, 57(1), 3-15.

Cooper, J. A. G., \& Pilkey, O. H. (2012). Introduction. In J. A. G. Cooper \& O. H. Pilkey (Eds.), Pitfalls of shoreline stabilization: Selected case studies (pp. xi-xiv). Dordrecht: Springer.

Costas, S., Ferreira, O., \& Martinez, G. (2015). Why do we decide to live with risk at the coast? Ocean \& Coastal Management, 118, 1-11.

Dangendorf, S., Marcos, M., Woppelmannc, G., Conrad, C. P., Frederikse, T., \& Riva, R. (2017). Reassessment of $20^{\text {th }}$ century global mean sea level rise. Proceedings of the National Academy of Sciences of the United States of America, 114(23), 5946-5951.

Dannevig, H., \& Hovelsrud, G. K. (2016). Understanding the need for adaptation in a natural resource dependent community in northern Norway: Issue salience, knowledge and values. Climatic Change, 135(2), 261-275.

Dean, A., Green, D., \& Nunn, P. D. (2016). Too much sail for a small craft? Donor requirements, scale, and capacity discourses in Kiribati. In E. Stratford (Ed.), Island geographies: Essays and conversations (pp. 67-88). London: Routledge.

Deidda, M. (2016). Insularity and economic development: a survey. International Review of Economics, 63, 107-128.

Dickinson, W. R. (2009). Pacific atoll living: How long already and until when. GSA Today, 19(3), 4.

Donner, S. D. (2015). The legacy of migration in response to climate stress: Learning from the Gilbertese resettlement in the Solomon Islands. Natural Resources Forum, 39(3-4), 191-201. 
Doumenge, F. (1987). Quelques contraintes du milieu insulaire. In Groupe de recherche sur la viabilité des pays insulaires (Ed.), Iles Tropicales: Insularité, Insularisme (pp. 9-16). Bordeaux: CRET, Université de Bordeaux III.

Dreher, T., \& Voyer, M. (2015). Climate refugees or migrants? Contesting media frames on climate justice in the Pacific. Environmental Communication - A Journal of Nature and Culture, 9(1), 58-76.

Duvat, V., Magnan, A., \& Pouget, F. (2013). Exposure of atoll population to coastal erosion and flooding: A South Tarawa assessment, Kiribati. Sustainability Science, 8(3), 423-440.

Edwards, J. B. (2013). The logistics of climate-induced resettlement: lessons from the Carteret Islands, Papua New Guinea. Refugee Survey Quarterly, 32(3), 52-78.

Encontre, P. (1999). The vulnerability and resilience of Small Island Developing States in the context of globalization. Natural Resources Forum, 23, 261-270.

Farbotko, C., \& Lazrus, H. (2012). The first climate refugees? Contesting global narratives of climate change in Tuvalu. Global Enironmental Change-Human and Policy Dimensions, 22(2), 382-390.

Foale, S., Cohen, P., Januchowski-Hartley, S., Wenger, A., \& Macintyre, M. (2011). Tenure and taboos: Origins and implications for fisheries in the Pacific. Fish and Fisheries, 12(4), 357-369.

Forsyth, T. (2013). Community-based adaptation: A review of past and future challenges. WIREs Climate Change, 4(5), 439-446.

Fujita, K., Nagamine, S., Ide, Y., Umezawa, Y., Hosono, T., Kayanne, H., \& Yamano, H. (2014). Distribution of large benthic foraminifers around a populated reef island: Fongafale Island, Funafuti Atoll, Tuvalu. Marine Micropaleontology, 113, 1-9.

Gharbaoui, D., \& Blocher, J. (2016). The reason land matters: Relocation as adaptation to climate change in Fiji Islands. In A. Milan, B. Schraven, K. Warner, \& N. Cascone (Eds.), Migration, risk management and climate change: Evidence and policy responses (pp. 149-173). Cham, Switzerland: Springer International Publishing.

Gillis, J. R. (2014). Not continents in miniature: Islands as ecotones. Island Studies Journal, 9(1), 155-166.

Gilman, E. L., Ellison, J., Jungblut, V., Van Lavieren, H., Wilson, L., Areki, F., .. . Yuknavage, K. (2006). Adapting to Pacific Island mangrove responses to sea level rise and climate change. Climate Research, 32(3), 161-176.

Head, L. (2016). Hope and grief in the anthropocene. New York: Routledge.

Henly-Shepard, S., McNamara, J. P., \& Bronen, R. (2018). Stories of climate change and mobility from around the world: Institutional challenges and implications for community development. In L. Shevellar \& P. Westoby (Eds.), The Routledge handbook of community development research (pp. 197-209). London: Routledge. 
Hermann, E., \& Kempf, W. (2017). Climate change and the imagining of migration: Emerging discourses on Kiribati's land purchase in Fiji. The Contemporary Pacific, 29(2), 231-263.

Ireland, P., \& McKinnon, K. (2013). Strategic localism for an uncertain world: A postdevelopment approach to climate change adaptation. Geoforum, 47, 158166.

Jackson, C. W., Bush, D. M., \& Neal, W. J. (2012). Documenting beach loss in front of seawalls in Puerto Rico: Pitfalls of engineering a small island nation shore. In J. A. G. Cooper \& O. H. Pilkey (Eds.), Pitfalls of shoreline stabilization: Selected case studies (pp. 53-72). Dordrecht: Springer.

Jaini, M., Advani, S., Shanker, K., Oommen, M. A., \& Namboothri, N. (2018). History, culture, infrastructure and export markets shape fisheries and reef accessibility in India's contrasting oceanic islands. Environmental Conservation, 45(1), 41-48.

Jamero, M. L., Onuki, M., Esteban, M., Billones-Sensano, X. K., Tan, N., Nellas, A., . . V Valenzuela, V. P. (2017). Small-island communities in the Philippines prefer local measures to relocation in response to sea-level rise. Nature Climate Change, 7(8), 581-586.

Janif, S., Nunn, P. D., Geraghty, P., Aalbersberg, W., Thomas, F. R., \& Camailakeba, M. (2016). Value of traditional oral narratives in building climate-change resilience: Insights from rural communities in Fiji. Ecology and Society, $21(2), 7$.

Johannes, R. E. (2002). The renaissance of community-based marine resource management in Oceania. Annual Review of Ecological Systems, 33, 317-340.

Johnston, I. (2014). Disaster management and climate change adaptation: A remote island perspective. Disaster Prevention and Management, 23(2), 123-137.

Kates, R. W., Travis, W. R., \& Wilbanks, T. J. (2012). Transformational adaptation when incremental adaptations to climate change are insufficient. Proceedings of the National Academy of Sciences, 109(19), 7156-7161.

Kelman, I. (2010). Hearing local voices from Small Island Developing States for climate change. Local Environment, 15(7), 605-619.

Kelman, I. (2014). No change from climate change: vulnerability and Small Island Developing States. Geographical Journal, 180(2), 120-129.

Kelman, I. (2018). Islandness within climate change narratives of Small Island Developing States (SIDS). Island Studies Journal, 13, 149-166.

Kempf, W. (2012). Climate change, migration, and Christianity in Oceania. In K. Hastrup \& K. F. Olwig (Eds.), Climate change and human mobility: Challenges to the social sciences. Cambridge: Cambridge University Press.

Kench, P. (2012). Compromising reef island shoreline dynamics: Legacies of the engineering paradigm in the Maldives. In J. A. G. Cooper \& O. H. Pilkey (Eds.), Pitfalls of shoreline stabilization: Selected case studies (pp. 165-186). Dordrecht: Springer. 
Khan, A., \& Amelie, V. (2015). Assessing climate change readiness in Seychelles: Implications for ecosystem-based adaptation mainstreaming and marine spatial planning. Regional Environmental Change, 15(4), 721-733.

Kumar, L., Eliot, I., Nunn, P. D., Stul, T., \& McLean, R. (2018). An indicative index of physical susceptibility of small islands to coastal erosion induced by climate change: An application to the Pacific islands. Geomatics, Natural Hazards and Risk, 9(1), 691-702.

Kuruppu, N., \& Willie, R. (2015). Barriers to reducing climate enhanced disaster risks in Least Developed Country-Small Islands through anticipatory adaptation. Weather and Climate Extremes, 7, 72-83.

Mackay, S., Brown, R., Gonelevu, M., Pelesikoti, N., Kocovanua, T., Iaken, R., . . . Mackey, B. (2018). Overcoming barriers to climate change information management in Small Island Developing States: Lessons from Pacific SIDS. Climate Policy, 1-14.

Magnan, A. K., \& Duvat, V. K. E. (2018). Unavoidable solutions for coastal adaptation in Reunion Island (Indian Ocean). Environmental Science \& Policy, 89, 393-400.

Martin, J.-L., Maris, V., \& Simberloff, D. S. (2016). The need to respect nature and its limits challenges society and conservation science. Proceedings of the National Academy of Sciences, 113(22), 6105-6112.

Martin, P., Nunn, P. D., Leon, J., \& Tindale, N. (2018). Responding to multiple climate-linked stressors in a remote island context: The example of Yadua Island, Fiji. Climate Risk Management, 21, 7-15.

Maru, Y. T., Stafford Smith, M., Sparrow, A., Pinho, P. F., \& Dube, O. P. (2014). A linked vulnerability and resilience framework for adaptation pathways in remote disadvantaged communities. Global Environmental Change, 28, 337-350.

McNamara, K. E., \& Jacot des Combes, H. (2015). Planning for community relocations due to climate change in Fiji. International Journal of Disaster Risk Science, 6(3), 315-319.

McNamara, K. E., \& Prasad, S. S. (2014). Coping with extreme weather: Communities in Fiji and Vanuatu share their experiences and knowledge. Climatic Change, 123(2), 121-132.

Mengel, M., Levermann, A., Frieler, K., Robinson, A., Marzeion, B., \& Winkelmann, R. (2016). Future sea level rise constrained by observations and long-term commitment. Proceedings of the National Academy of Sciences of the United States of America, 113(10), 2597-2602.

Mercer, J., Dominey-Howes, D., Kelman, I., \& Lloyd, K. (2007). The potential for combining indigenous and western knowledge in reducing vulnerability to environmental hazards in small island developing states. Environmental Hazards, 7(4), 245-256.

Mertz, O., Bruun, T. B., Fog, B., Rasmussen, K., \& Agergaard, J. (2010). Sustainable land use in Tikopia: Food production and consumption in an isolated agricultural system. Singapore Journal of Tropical Geography, 31(1), 10-26. 
Mimura, N., Nurse, L., McLean, R. F., Agard, J., Briguglio, L., Lefale, P., . . Sem, G. (2007). Small islands. In M. L. Parry, O. F. Canziani, J. P. Palutikof, P. J. van der Linden, \& C. E. Hanson (Eds.), Climate Change 2007: Impacts, adaptation and vulnerability. Contribution of Working Group II to the Fourth Assessment Report of the Intergovernmental Panel on Climate Change (pp. 687-716). Cambridge: Cambridge University Press.

Moffitt, D. L., \& Kumar, L. (2018). Remote sensing of a shallow, fringing reef platform for analysis of island sector susceptibility and development of a coastal vulnerability index. Journal of Coastal Research, 34(1), 122-135.

Mohan, P., \& Strobl, E. (2017). A hurricane wind risk and loss assessment of Caribbean agriculture. Environment and Development Economics, 22(1), 84-106.

Moser, S. C. (2014). Communicating adaptation to climate change: The art and science of public engagement when climate change comes home. WIREs Climate Change, 5(3), 337-358.

Nunn, P. D. (2007). Climate, environment and society in the Pacific during the last millennium. Amsterdam: Elsevier.

Nunn, P. D. (2009). Responding to the challenges of climate change in the Pacific Islands: Management and technological imperatives. Climate Research, 40(2-3), 211-231.

Nunn, P. D. (2010). Bridging the gulf between science and society: Imperatives for minimizing societal disruption from climate change in the Pacific. In K. Fukushi \& A. Hiramatsu (Eds.), Adaptation and mitigation strategies for climate change (pp. 233-248). Berlin: Springer.

Nunn, P. D. (2013). The end of the Pacific? Effects of sea level rise on Pacific Island livelihoods. Singapore Journal of Tropical Geography, 34(2), 143-171.

Nunn, P. D., Aalbersberg, W., Lata, S., \& Gwilliam, M. (2014). Beyond the core: community governance for climate-change adaptation in peripheral parts of Pacific Island Countries. Regional Environmental Change, 14(1), 221-235.

Nunn, P. D., Kumar, L., Eliot, I., \& McLean, R. F. (2016). Classifying Pacific islands. Geoscience Letters, 3(1), 1-19.

Nunn, P. D., \& Kumar, R. (2018). Understanding climate-human interactions in Small Island Developing States (SIDS): Implications for future livelihood sustainability. International Journal of Climate Change Strategies and Management, 10(2), 245-271.

Nunn, P.D. \& Kumar, R. (2019a). Cashless adaptation to climate change in developing countries: unwelcome yet unavoidable? One Earth, 1, 31-34.

Nunn, P.D. \& Kumar, R. (2019b). Measuring peripherality as a proxy for autonomous community coping capacity: A case study from Bua Province, Fiji Islands, for improving climate change adaptation. Social Sciences, 8(8), \#225.

Nunn, P. D., Mulgrew, K., Scott-Parker, B., Hine, D. W., Marks, A. D. G., Mahar, D., \& Maebuta, J. (2016). Spirituality and attitudes towards Nature in the 
Pacific Islands: Insights for enabling climate-change adaptation. Climatic Change, 136(3-4), 477-493.

Nurse, L., McLean, R., Agard, J., Briguglio, L. P., Duvat, V., Pelesikoti, N., . . . Webb, A. (2014). Small islands. In V. R. Barros, C. B. Field, D. J. Dokken, M. D. Mastrandrea, K. J. Mach, T. E. Bilir, M. Chatterjee, K. L. Ebi, Y. O. Estrada, R. C. Genova, B. Girma, E. S. Kissel, A. N. Levy, S. MacCracken, P. R. Mastrandrea, \& L. L. White (Eds.), Climate Change 2014: Impacts, adaptation, and vulnerability. Part B: Regional aspects. Contribution of Working Group II to the Fifth Assessment Report of the Intergovernmental Panel on Climate Change. Cambridge: Cambridge University Press.

Odalen, J. (2014). Underwater self-determination: Sea-level rise and deterritorialized Small Island States. Ethics Policy \& Environment, 17(2), 225-237.

Oost, A. P., Hoekstra, P., Wiersma, A., Flemming, B., Lammerts, E. J., Pejrup, M., ... Wang, Z. B. (2012). Barrier island management: Lessons from the past and directions for the future. Ocean \& Coastal Management, 68, 18-38.

Paton, K., \& Fairbairn-Dunlop, P. (2010). Listening to local voices: Tuvaluans respond to climate change. Local Environment, 15(7), 687-696.

Patt, A. G., \& Schroter, D. (2008). Perceptions of climate risk in Mozambique: Implications for the success of adaptation strategies. Global Environmental Change-Human and Policy Dimensions, 18(3), 458-467.

Pelling, M., \& Uitto, J. I. (2001). Small island developing states: Natural disaster vulnerability and global change. Global Environmental Change Part B: Environmental Hazards, 3(2), 49-62.

Piggott-McKellar, A., McNamara, K., Nunn, P. D., \& Watson, J. (2019). What are the barriers to successful community-based climate change adaptation? A review of grey literature. Local Environment, 24(4), 374-390.

Piggott-McKellar, A., McNamara, K.E., Nunn, P.D. and Sekinini, S. (2019). Moving people in a changing climate: lessons from two case studies in Fiji. Social Sciences, 8(5), \#133.

Pittman, J., Armitage, D., Alexander, S., Campbell, D., \& Alleyne, M. (2015). Governance fit for climate change in a Caribbean coastal-marine context. Marine Policy, 51, 486-498.

Remling, E., \& Veitayaki, J. (2016). Community-based action in Fiji's Gau Island: A model for the Pacific? International Journal of Climate Change Strategies and Management, 8(3), 375-398.

Robie, D. (2014). "Carbon colonialism": Pacific environmental risk, media credibility and a deliberative perspective. Pacific Journalism Review, 20(2), 59-76.

Robinson, S. (2017). Climate change adaptation trends in Small Island Developing States. Mitigation and Adaptation Strategies for Global Change, 22(4), 669-691.

Romine, B. M., \& Fletcher, C. H. (2012). Armoring on eroding coasts leads to beach narrowing and loss on Oahu, Hawaii. In J. A. G. Cooper \& O. H. 
Pilkey (Eds.), Pitfalls of shoreline stabilization: Selected case studies (pp. 141-164). Dordrecht: Springer.

Rudiak-Gould, P. (2014). The influence of science communication on indigenous climate change perception: Theoretical and practical implications. Human Ecology, 42(1), 75-86.

Sattler, D. N. (2017). Climate change and extreme weather events: The mental health impact. In W. Leal Filho (Ed.), Climate change adaptation in Pacific countries: Fostering resilience and improving the quality of life (pp. 73-85). Cham, Switzerland: Springer International Publishing.

Schulte, D. M., Dridge, K. M., \& Hudgins, M. H. (2015). Climate change and the evolution and fate of the Tangier Islands of Chesapeake Bay, USA. Scientific Reports, 5, 17890.

Scott-Parker, B., \& Kumar, R. (2018). Fijian adolescents' understanding and evaluation of climate change: Implications for enabling effective future adaptation. Asia Pacific Viempoint, 59(1), 47-59.

Scott-Parker, B., Nunn, P. D., Mulgrew, K., Hine, D., Marks, A., Mahar, D., \& Tiko, L. (2017). Pacific Islanders' understanding of climate change: Where do they source information and to what extent do they trust it? Regional Environmental Change, 17(4), 1005-1015.

Singh-Peterson, L., \& Iranacolaivalu, M. (2018). Barriers to market for subsistence farmers in Fiji - a gendered perspective. Joumal of Rural Studies, 60, 11-20.

Stratford, E. (2008). Islandness and struggles over development: A Tasmanian case study. Political Geography, 27(2), 160-175.

Travis, W. R., Smith, J. B., \& Yohe, G. W. (2018). Moving toward 1.5 degrees C of warming: Implications for climate adaptation strategies. Current Opinion in Environmental Sustainability, 31, 146-152.

Walsh, K. J. E., McBride, J. L., Klotzbach, P. J., Balachandran, S., Camargo, S. J., Holland, G., . . . Sugi, M. (2016). Tropical cyclones and climate change. WIREs Climate Change, 7(1), 65-89.

Wang, Y. P., Shi, B. W., Zhang, L., Jia, J. J., Xia, X. M., Zhou, L., . . Gao, J. H. (2017). Assessing the vulnerability of changing coasts, Hainan Island, China. Acta Oceanologica Sinica, 36(4), 114-120.

Warrington, E., \& Milne, D. (2018). Governance. In G. Baldacchino (Ed.), The Routledge international handbook of island studies: A world of islands (pp. 173-201). London: Routledge. 